Gut, 1968, 9, 96-98

\title{
Alkaline phosphatase levels in normal and diseased small bowel
}

\author{
ANNE FERGUSON, W. C. WATSON, J. D. MAXWELL, AND G. S. FELL \\ From the University Department of Medicine and the Department of Biochemistry, \\ Royal Infirmary, Glasgow
}

Since the introduction of peroral biopsy of the small intestine (Shiner, 1956; Crosby and Kugler, 1957) there has been growing interest in intestinal enzymes as well as morphology. The disaccharidases have received most attention, but many other enzymes, including alkaline phosphatase, are present in the small intestinal mucosa.

There are few reports on human intestinal alkaline phosphatase and its function is not yet completely understood. Bolt, Pollard, and $\mathrm{McCool}$, (1960), using histochemical techniques on peroral biopsy tissue, identified alkaline phosphatase in the epithelial cell and brush border. They stated that enzyme activity was diminished in patients with 'primary sprue'. Plosscowe, Berg, and Segal (1963), also using a histological technique, found no significant difference in alkaline phosphatase activity between the jejunal biopsy specimens of 20 normals, 10 patients with primary malabsorption (nontropical sprue), and two with pernicious anaemia.

In this study we have established a range of alkaline phosphatase values for normal human jejunum, and report the deviations from normal when the histology of the jejunum is abnormal.

\section{METHODS}

Jejunal biopsies were obtained with the Crosby capsule, as previously described (Watson, Paton, and Murray, 1965). The position of the capsule was checked radiologically in every case, and was within the first $10 \mathrm{~cm}$. of the jejunum.

After removal from the capsule, the tissue was washed in saline, spread on filter paper with the epithelial surface up, and divided into two portions. One was sent for histology. The other was weighed on a microtorsion balance, homogenized in ice-cold water and brought to a final concentration of $10 \mathrm{mg} . / \mathrm{ml}$. Some of this homogenate was used for the estimation of disaccharidase activity (maltase, sucrase, and lactase) as described by Dahlqvist (1964), with minor modifications as previously described (Paton, Murray, and Watson, 1966). The remainder of the homogenate was diluted 1 in 10 and estimated for alkaline phosphatase activity by the method of Kind and King (1954) as modified for the autoanalyser by Marsh, Fingerhut and Kirsch (1959) and Axelsson, Ekman, and Knutsson (1965). Most of the alkaline phosphatase in an intestinal homogenate is in a particulate form (Morton, 1954; Triantaphyllopoulos and Tuba, 1959). The constant agitation of the sample during its passage through the autoanalyser keeps the particles in a state of suspension. After a suitable incubation time, the sample is dialysed and so the products of the phosphatase activity can be determined colorimetrically without turbidity effects caused by the particulate matter. Near maximum values are obtained, as can be demonstrated by comparisons of autoanalyser determinations on standard homogenates with homogenates in which the alkaline phosphatase had been brought into solution by incubation with butanol for one hour at $37^{\circ} \mathrm{C}$. (Morton, 1954).

On the basis of dissecting and conventional microscope appearances, tissues were allocated to one of three groups: 'normal', with finger or leaf villi present; 'ridged', with mucosal ridges seen under the dissecting microscope, but fairly normal appearance on section; and 'flat', with partial or subtotal villous atrophy.

\section{RESULTS}

The range of normal jejunal alkaline phosphatase levels (King Armstrong units per gram tissue) was based on the results from 30 patients (eight male, 22 female) average age 38 years (range 18-68) with normal histology and normal disaccharidase activity, based on previously established control levels (Paton et al, 1966). The diagnoses included the irritable colon syndrome, diabetes, treated pernicious anaemia, and myxoedema. The subjects were in good general health, eating a normal diet and not losing weight. The results are summarized in Table I. The mean jejunal alkaline phosphatase activity for this group is 162 K.A. units/g. tissue (range of 60 to 269; S.D. 59).

In the same Table are shown the data for 22 patients, with partial or subtotal villous atrophy. In all cases, there was deficiency of the three disaccharidases estimated. In 16 of these patients the diagnosis was adult coeliac disease; two patients 
TABLE I

SUMMARY OF DISACCHARIDASE LEVELS (UNITS OF ACTIVITY/ G. TISSUE) AND ALKALINE PHOSPHATASE ACTIVITY (K.A. UNITS/G. TISSUE) IN 30 'NORMAL' CONTROLS AND 22 PATIENTS WITH JEJUNAL VILLOUS ATROPHY

\begin{tabular}{llcl} 
Histology & & Normal (30) & $\begin{array}{l}\text { Villous } \\
\text { Atrophy (22) }\end{array}$ \\
\hline Lactase & Mean & $3 \cdot 7$ & 0.07 \\
& S.D. & $1 \cdot 7$ & 0.17 \\
Sucrase & Mean & $5 \cdot 6$ & 0.9 \\
& S.D. & $1 \cdot 7$ & 0.6 \\
Maltase & Mean & 21.0 & 2.9 \\
& S.D. & $7 \cdot 2$ & 1.8 \\
Alkaline1 & Mean & 162 & 25 \\
phosphatase & S.D. & 59 & 19
\end{tabular}

'Difference between groups is highly significant $(p<0.001)$

had rosacea; diagnoses for the others were Crohn's disease, Whipple's disease, mesenteric ischaemia, and dermatitis herpetiformis. The mean jejunal alkaline phosphatase levels for this group of patients is 25 K.A. units/g. tissue (range of 9 to 85; S.D. 19).

The difference between the two groups of Table I is highly significant.

Tissues in which there was a moderate abnormality of histology or disaccharidase activity were divided into three groups. Jejunal alkaline phosphatase activities for these groups are shown in Figure 1. Twelve patients had normal histology,

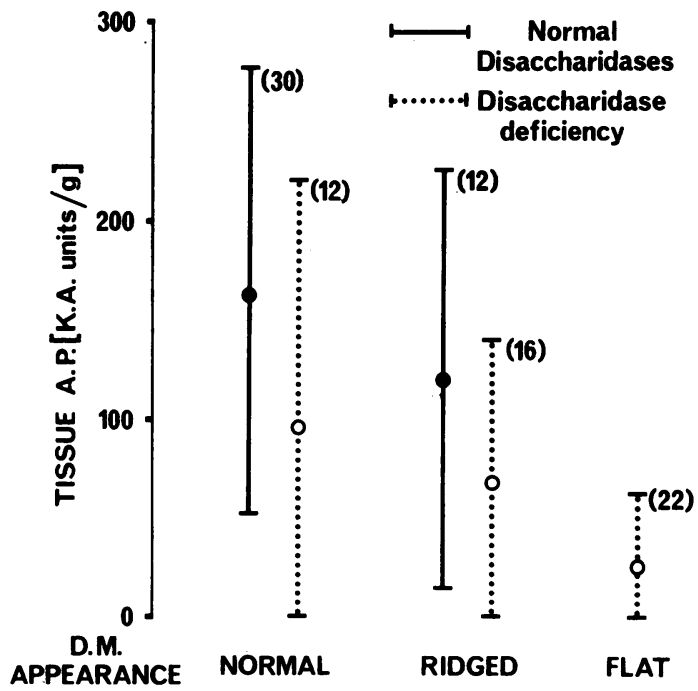

FIG. 1. Chart showing tissue alkaline phosphatase levels (mean \pm 2 S.D.) in five groups, classified according to dissecting microscope appearance and disaccharidase levels. The number of patients in each group is shown in brackets. with deficiency of two or more disaccharidases. In 28 cases the mucosa appeared ridged; in 12 of these disaccharide levels were normal, and there was disaccharidase deficiency in 16. Cases of isolated disaccharidase deficiency in an otherwise normal mucosa have been excluded. In all three groups, alkaline phosphatase activity was significantly lower than in the normal group.

\section{DISCUSSION}

Using standard techniques, the levels of alkaline phosphatase activity in normal and diseased small bowel have been established. We concede that our control data are not from completely normal individuals but we are confident that the basis of selection makes it likely that the data represent the range of values in normal jejunal tissue.

A level of $60 \mathrm{~K}$.A. units/g. tissue has been taken as the lower limit of normal. In all but one of the 22 patients with partial or subtotal villous atrophy, the tissue alkaline phosphatase activity was below this level.

The gradient of alkaline phosphatase activity in human small bowel has not previously been investigated but a gradient has been shown to exist in the rat intestine (Triantaphyllopoulos and Tuba, 1959; Watson, Murray, and Gardner, 1967). Highest levels are found in the duodenum and lowest in the terminal ileum. Support for the assumption that there is a gradient in the human came from investigation of two patients with ileostomies after surgery for ulcerative colitis. Ileal biopsies were obtained using Wood's gastric biopsy tube, and the paired results for jejunum and ileum were 218 and 61 , and 42 and 10 K.A. units/g. tissue respectively.

In the adult human, disaccharidase activity is usually lower in the duodenum than in the jejunum (Watson and Murray, 1965; Newcomer and McGill, 1966). Three histologically normal samples were obtained from duodenum, and in these alkaline phosphatase activity was normal although there was low disaccharidase activity.

Where there is a ridged or flat mucosa, the number of epithelial cells is less than normal (Creamer, 1964). Alkaline phosphatase activity is below normal in these tissues and it is possible that this is due only to a reduction in the number of cells containing alkaline phosphatase. However, in some tissues with normal histology, low alkaline phosphatase levels were obtained. Diagnoses for the patients concerned included myxoedema, ulcerative colitis, rosacea, and chronic renal failure. This indicates that, in a variety of clinical states, there is a reduction in the alkaline phosphatase content of the individual epithelial cell. 


\section{SUMMARY}

Alkaline phosphatase levels have been estimated in normal and abnormal human jejunum. For 30 normal tissues the range was 60 to 296 K.A. units/g. mucosa (mean 162 and S.D. 59). For 22 tissues with mucosal atrophy due principally to adult coeliac disease, and associated with generalized severe disaccharidase deficiency, the range was 9 to 85 K.A. units/g. mucosa (mean 25 and S.D. 19).

Although the most direct cause of diminished intestinal alkaline phosphatase activity is villous atrophy, irrespective of the primary disease, the enzyme levels may also be depleted in histologically normal tissue in association with other diseases of a type which suggest that toxic, endocrine, or metabolic factors may exert control.

We are grateful to Drs. D. Murray and A. Mackay of the University Department of Pathology for the small bowel histology, and to the physicians of the Royal Infirmary who refer cases to us. The intestinal disaccharidases were estimated by Miss Elspeth Murray, B.Sc. This part of the work was supported by a Scottish Hospitals Endowment Research Trust grant no. 164.

\section{REFERENCES}

Axelsson, H., Ekman, B., and Kuntsson, D. (1965). Personal Communication.
Bolt, R. J., Pollard, H. M., and McCool, S. (1960). Staining of enzymes in mucosa of the small bowel, using a peroral biopsy tube. Amer. J. clin. Path., 34, 43-49.

Creamer, B. (1964). Variations in small-intestinal villous shape and mucosal dynamics. Brit. med. J., 2, 1371-1373.

Crosby, W. H., and Kugler, H. W. (1957). Intraluminal biopsy of the small intestine: the intestinal biopsy capsule. Amer. J. dig. Dis., 2, 236-241.

Dahlqvist, A. (1964). In Disorders due to intestinal defective carbohydrate digestion, edited by P. Durand. pp. 5-56. I1 Penserio Scientifico, Rome.

Kind, P. R. N., and King, E. J. (1954). Estimation of plasma phosphatase by determination of hydrolysed phenol with aminoantipyrene. J. clin. Path., 7, 322-326.

Marsh, W. H., Fingerhut, B., and Kirsch. E. (1959). Adaptation of an alkaline phosphatase method for automatic colorimetric analysis. Clin. Chem., 5, 119-126.

Morton, R. K. (1954). The purification of alkaline phosphatases of animal tissues. Biochem. J., 57, 595-603.

Newcomer, A. D., and McGill, D. B. (1966). Distribution of disaccharidase activity in the small bowel of normal and lactasedeficient subjects. Gastroenterology, 51, 481-488.

Paton, E., Murray, E. S., and Watson, W. C. (1966). Intestinal disaccharidase activity in rosacea. Brit. med. J., 1, 459-460.

Plosscowe, R. P., Berg, G. G., and Segal, H. L. (1963). Enzyme histochemical studies of human gastric and jejunal biopsy specimens in normal and diseased states. Amer. J. dig. Dis., 8, 311-318.

Shiner, M. (1956). Duodenal biopsy. Lancet, 1, 17-19.

Triantaphyllopoulos, E., and Tuba, J. (1959). Studies on the distribution and kinetics of the alkaline phosphatase of rat small intestine. Canad. J. Biochem., 37, 699-709.

Watson, W. C., and Murray, E. S. (1965). Unpublished observations.

-, Paton, E., and Murray, D. (1965). Small-bowel disease in rosacea. Lancet, 2, 47-50.

-, Murray, E. S., and Gardner, M. D. (1967). Regulations of intestinal alkaline phosphatase levels in the rat. J.clin. Path. 20 , 185-189. 